DOI: https://doi.org/10.26682/sjuod.2020.23.1.5

Journal of University of Duhok, Vol. 23, No.1 (Pure and Eng. Sciences), Pp 41-50, 2020

\title{
DETERMINATION OF ANTIOXIDANT ACTIVITY FOR METAL IONS COMPLEXES
}

\author{
Vian Yamin JirJees,Veyan Taher Suleman ${ }^{*}$, SuZan Duraid Ahmed ${ }^{* *}$ and Abbas Ali Salih Al- \\ HAMDANI $^{* * *}$ \\ "Dept. of Chemistry, College Of Science, University Of Duhok, Kurdistan Region-Iraq \\ ** Dept. of Chemistry, College of Education for pure Science,University of Baghdad-Iraq \\ ${ }^{* * *}$ Dept. of Chemistry, College of Science for Women, University of Baghdad-Iraq.
}

(Received: September 15, 2019; Accepted for Publication: February 17, 2020)

\begin{abstract}
The synthesis and characterization of Schiff base and the complexities of metal ions and the evaluation of its antioxidant activities against 1.1-Diphenyl-2-picrylhydrazyl (DPPH) will compared with standard natural antioxidants and ascorbic acid. These prepared materials gave results are due exhibit excellent radical scavenging activities for all complexes with new prepared from reaction Schiff base and metal ions for [ $\mathrm{Mn}(\mathrm{II}), \mathrm{Zn}$ (II), $\mathrm{Cd}(\mathrm{II}), \mathrm{Pd}(\mathrm{II})$ and $\mathrm{Hg}(\mathrm{II})$ ]. The complexes prepared characterization by spectral methods (ultraviolet visible, infrared and mass spectra) will be identified in addition to the element micro analysis, (F.A.A.), magnetic sensitivity. The molar conductance values indicated that the complexes derived from $\mathrm{Mn}$ (II), $\mathrm{Zn}$ (II), $\mathrm{Cd}$ (II), $\mathrm{Hg}$ (II) chloride and Pd(II) bromide have nonelectrolytic nature. IR spectra indicated that the ligand acts as neutral bidentate moiety in all complexes. According to the results of diagnosis and analysis gave the all complexes form tetrahedral except in Pd (II) complex square planar. The antioxidant activities of the metal complexes will be examined using the DPPH radical scavenging method the compounds exhibited antioxidant properties of scavenging free radicals.
\end{abstract}

KEY WORDS: Schiff base Complexes, 1,1-Diphenyl-2-picrylhydrazyl (DPPH), Antioxidant activities, synthesis.

https://doi.org/10.26682/sjuod.2020.23.1.5

\section{INTRODUCTION}

A ntioxidants of Schiff base and its complexes are in general donors to hydrogen or electron donors into interactive site on neutralizing free radicals $[1,2]$. Scavenging efficacy of various organic compounds can be evaluated utilizing DPPH free radical, And also $\mathrm{ABTS}^{+}$tests. Many organic molecules have already been notified that act as anti-oxidants are very good, so it is paramount to understand the method of action as well efficacy from these antioxidants. There are large numbers of normal as well synthetic anti-oxidants whom will explored; also their anti-oxidant ability will be evaluated through different ways [3]. A search through literature [4-6] reveals that no work has been done on the ions metal complexes of the Schiff base 6((4-Dimethylaminobenzylidene aminopyridine-2, 4 diol. In order to investing anew antioxidant agent, which may be applied later in pharmaceutical uses. We examined the antioxidant activity and the inhibition effect of four complexes from Manganese, Zinc, Cadmium, Palladium and Mercury the prepared from reaction with Schiff base, using the UV-visible method and the standard natural antioxidant (DPPH) radical, ascorbic acid.

\section{EXPERIMENTAL}

\subsection{Material and methods}

Element microanalyses (C.H.N.) through employing, Conductivity measurements utilizing a Philips PW-digital, Magnetic moments have been measured for a magnetic susceptibility balance (Sherwood balance magnetic susceptibility model MSB-MK).UV-Visible spectra will recorded using (Shimadzu1800A) spectrophotometer. IR spectral has been acquired employing Shimadzu, (8400S) FT-IR spectrometer. Mass spectra to all complexes will recorded on MS Model 5973 Network Mass Selection Technology (HP) with Triple -Axis Detector by the analyzer Quadrupole at $230{ }^{\circ} \mathrm{C}$. Melting points byusing stuart- 
10capillary. Metals\% will be determined by a Shimadzu (F.A. A) $620 \mathrm{G}$

All other organic chemicals, solvents and inorganic salts will be available from multiple companies, Fluk, B.D.H , Merck , sigma and Alderich and used without further purification.

2.2 Synthesis of Ligand: 6-((4Dimethylaminobenzylidene aminopyridine-2, 4 $\operatorname{diol}\left(\mathrm{H}_{2} \mathbf{L}\right)(7)$

4- Dimethylaminobenzaldehyde (1g or 6.8 mmole) will be dissolved in ethanol $(20 \mathrm{ml})$ with stirring. 4-amino-2,6-dihydroxypyrimidine ( $0.8643 \mathrm{~g}$ or $6.8 \mathrm{mmole})$ was dissolved in ethanol $(25 \mathrm{ml})$ and added 3 drops with hydrochloride acid as a catalyst. The mixture solution will be heated under reflux at temperature $\left(60-70{ }^{\circ} \mathrm{C}\right)$ for six hours until the precipitation of the red solid will be complete. Then, the solid collected by filtration and washed by water $\left(10 \mathrm{~cm}^{3} \times 3\right)$, dried at temperature $\left(50^{\circ} \mathrm{C}\right)$ for three hours and then recrystalized from absolute methanol. The red light crystals will collect by filtration and then dried at temperature $50{ }^{\circ} \mathrm{C}$ for six hours. After that, the product precipitated (m.p. $=241^{\circ} \mathrm{C}$ ), (yield 84.4\%),Scheme-1. ${ }^{1} \mathrm{H}-\mathrm{NMR}-\mathrm{DMSO}-\mathrm{d}_{6}$, ppm: (single, $\mathrm{N}=\mathrm{C}-\mathrm{H}$ azomethine) 9.623, (molty, aromatic-C-H) 8.135-7.838, (single, $\mathrm{O}-\mathrm{H}$ phenol) 6.623, (molty, $\left.\mathrm{N}-\left(\mathrm{CH}_{3}\right)_{2}\right)$ 3.512-3.337. (Fig. 1) and Mass spectrometry will successfully utilized to explore molecular types at solution. Mass spectrum pattern from $\mathbf{H}_{2} \mathbf{L}$ ligand confirms the probable formula and gives an impression of the successive fragmentations to the aim compound for a chain from peaks corresponding into diverse fragments. LC-Mass spectrum to the ligand appeared delicate parent molecular ion peak on $\mathrm{m} / \mathrm{z}(257.9 \mathrm{amu})$ consistent for molecular weight theoretically. Spectrum predicted the monomeric nature of ligand. The series from peaks corresponding to degeneration for ligand appeared at $\mathrm{m} / \mathrm{z} 234.9,204.9$ and $73.4 \mathrm{amu}$ characterized to $\left[\mathrm{C}_{11} \mathrm{H}_{14} \mathrm{~N}_{4} \mathrm{O}_{2}\right]^{+},\left[\mathrm{C}_{11} \mathrm{H}_{14} \mathrm{~N}_{3} \mathrm{O}\right]^{+}$and $\left[\mathrm{C}_{3} \mathrm{H}_{9} \mathrm{~N}_{2}\right]^{+}$, respectively (Fig.

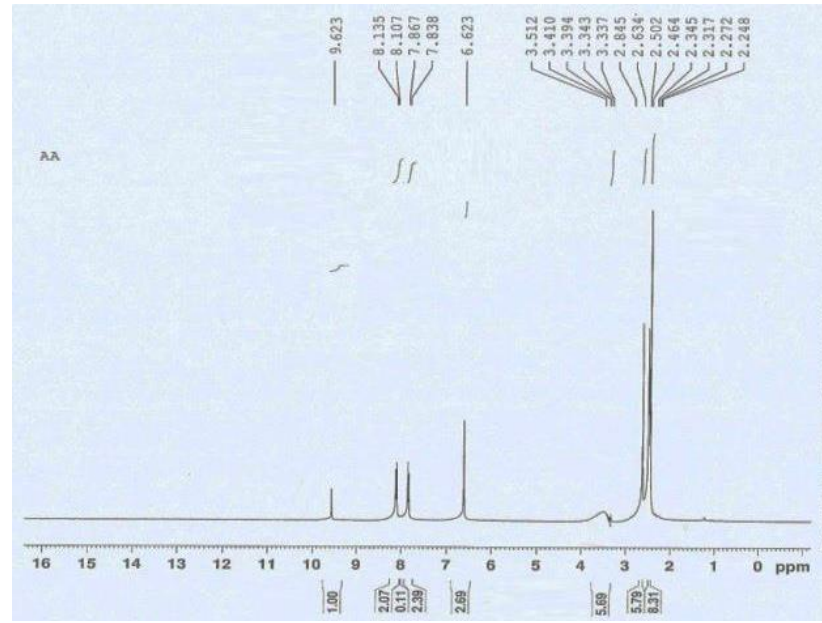

Fig. (1): ${ }^{1} \mathrm{H}-\mathrm{NMR}$ spectrum for $\left(\mathrm{H}_{2} \mathrm{~L}\right)$

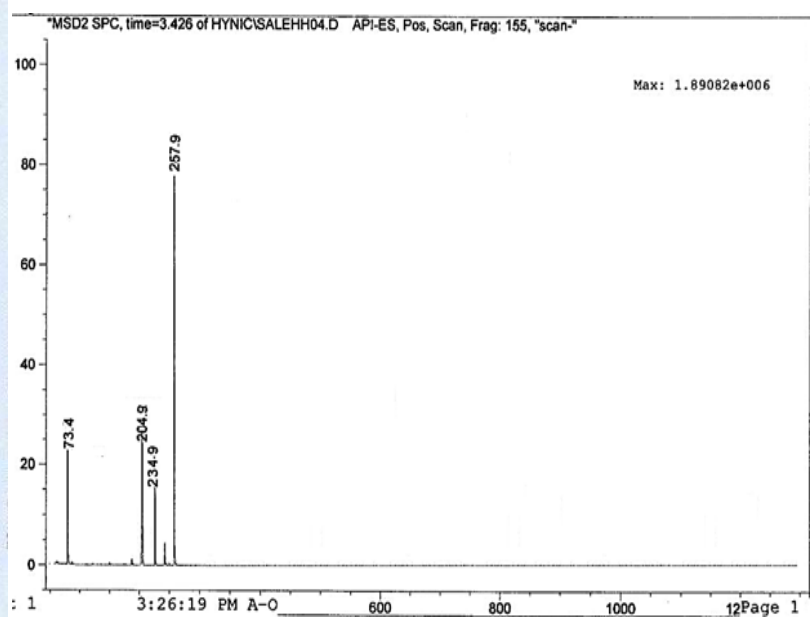

Fig. (2): Mass spectrum for ligand $\left(\mathrm{H}_{2} \mathrm{~L}\right)$

\subsection{Synthesis of Complexes}

The complexes will be prepared by addition solution $\left(\mathrm{H}_{2} \mathrm{~L}\right)(0.516 \mathrm{~g}, 2 \mathrm{mmol})$ with methanol to stirred aqueous solution of the respective metal(II) chloride $(0.136 \mathrm{~g}, 1 \mathrm{mmole}) \mathrm{ZnCl}_{2}$, $(0.201 \mathrm{~g}, 1 \mathrm{mmole})$ $\mathrm{CdCl}_{2} \cdot \mathrm{H}_{2} \mathrm{O}$, ( $\left.0.197 \mathrm{~g}, 1 \mathrm{mmol}\right) \mathrm{MnCl}_{2} \cdot 4 \mathrm{H}_{2} \mathrm{O}$, (.0.176.g, $1 \mathrm{mmole}) \mathrm{PdCl}_{2}$ and $(0.271 \mathrm{~g}, 1 \mathrm{mmole})$ $\mathrm{HgCl}_{2}$ in the stoichiometric ratio metal:ligand (1:2) after the mixture will refluxed for ( 6 hrs.) Leaving the solution in the laboratory. Then will filtered off and washed by acetone followed by drying at room temperature and analyzed

employing standard methods. Deposits have appeared in colors for complexes, red, yellow and pale brown for $\mathrm{Mn}(\mathrm{II}), \quad \mathrm{Pd}(\mathrm{II})$ and $\mathrm{Hg}(\mathrm{II})$ complexes, respectively. But the Zinc and Cadmium complexes will brown. The all complexes are non-soluble in water.

\subsection{Study of Antioxidant Activity using DPPH Method}

Each of the metal complexes will be dissolved in DMSO and ethanol to obtain concentration of $(10 \mathrm{mmol} \mathrm{1-1)}$. These stock solutions will then diluted to $(0.2,0.4,0.6,0.8$ and 
1 mmol.1-1). While gallic acid was used as standard. Then, $100 \mu \mathrm{L}$ of each sample solution will mix with $6 \mathrm{ml}$ of $45 \mu \mathrm{g} \mathrm{ml}^{-1} \mathrm{DPPH}$ that will dissolve in ethanol. The reaction mixture will be incubated in the dark place for (30 and $60 \mathrm{~min}$ ) at room temperature while DPPH reacts with antioxidants compounds. These compounds will donate hydrogen, it is reduced. Changes in color (from deep violet into light yellow). DPPH radical scavenging efficiency has been determined through measuring the absorbance on $517 \mathrm{~nm}$ utilizing the UV-Vis spectrometer the percentage from DPPH radical scavenger has been calculated employing Equation 1. [8]

$$
\% \text { Inhibition }=\frac{\mathrm{A}_{\text {Conttrol }}-\mathrm{A}_{\text {Test }}}{\mathrm{A}_{\text {Control }}} \times 100
$$

\section{RESULTS AND DISCUSSION}

All metal complexes have been synthesized during mole reaction. The formative complexes are stable, non-hygroscopic also partly soluble on most organic solvents like $\mathrm{CHCl} 3, \mathrm{CH} 3 \mathrm{OH}$, $\mathrm{C} 2 \mathrm{H} 5 \mathrm{OH}, \mathrm{C} 2 \mathrm{H} 3 \mathrm{~N}$, as well as fully dissolved on DMSO also DMF. A set from molar conductivity values registered on Table (1) elucidates that the complexes from manganese(II), zinc(II), cadmium(II), palladium(II) also Mercury(II) ions have non-electrolytic nature elucidating which each anions are involved in the chelation.

Table (1): Analytical and physical data of the ligand and its complexes

\begin{tabular}{|c|c|c|c|c|c|c|c|c|}
\hline \multirow[t]{2}{*}{ Compounds } & \multirow[t]{2}{*}{$\begin{array}{l}\text { Formula } \\
\text { M. wt }\end{array}$} & \multirow[t]{2}{*}{ Color } & \multirow[t]{2}{*}{$\begin{array}{l}\text { m.p } \\
{ }^{\circ} \mathbf{C}\end{array}$} & \multirow[t]{2}{*}{ yield } & \multicolumn{4}{|c|}{$\begin{array}{l}\text { Elemental micro analysis experimental } \\
\text { ( theoretical ) \% }\end{array}$} \\
\hline & & & & & $\mathrm{C}$ & $\mathrm{H}$ & $\mathrm{N}$ & $\mathrm{M}$ \\
\hline $\mathrm{H}_{2} \mathrm{~L}$ & $\begin{array}{l}\mathrm{C}_{13} \mathrm{H}_{14} \mathrm{~N}_{4} \mathrm{O}_{2} \\
258.28 \\
\end{array}$ & Light red & 241 & 84.4 & $\begin{array}{l}61.31 \\
(60.45) \\
\end{array}$ & $\begin{array}{l}4.49 \\
(5.46) \\
\end{array}$ & $\begin{array}{l}22.75 \\
(21.69) \\
\end{array}$ & \\
\hline $\mathrm{Mn}(\mathrm{HL})_{2}$ & $\begin{array}{l}\mathrm{C}_{26} \mathrm{H}_{26} \mathrm{~N}_{8} \mathrm{O}_{4} \mathrm{Mn} \\
569.47\end{array}$ & red & 289 & 86 & $\begin{array}{l}53.12 \\
(54.84) \\
\end{array}$ & $\begin{array}{l}4.05 \\
(4.60) \\
\end{array}$ & $\begin{array}{l}21.45 \\
(19.68) \\
\end{array}$ & $\begin{array}{l}10.11 \\
(9.65) \\
\end{array}$ \\
\hline $\mathrm{Zn}(\mathrm{HL})_{2}$ & $\begin{array}{l}\mathrm{C}_{26} \mathrm{H}_{26} \mathrm{~N}_{8} \mathrm{O}_{4} \mathrm{Zn} \\
579.93\end{array}$ & Brown & 282 & 76 & $\begin{array}{l}53.60 \\
(53.85) \\
\end{array}$ & $\begin{array}{l}5.16 \\
(4.52) \\
\end{array}$ & $\begin{array}{l}21.01 \\
(19.32) \\
\end{array}$ & $\begin{array}{l}9.66 \\
(11.28) \\
\end{array}$ \\
\hline $\mathrm{Cd}(\mathrm{HL})_{2}$ & $\begin{array}{l}\mathrm{C}_{26} \mathrm{H}_{26} \mathrm{~N}_{8} \mathrm{O}_{4} \mathrm{Cd} \\
626.95\end{array}$ & Brown & 195 & 71 & $\begin{array}{l}50.121 \\
(49.81) \\
\end{array}$ & $\begin{array}{l}3.98 \\
(4.18) \\
\end{array}$ & $\begin{array}{l}19.45 \\
(17.87) \\
\end{array}$ & $\begin{array}{l}18.09 \\
(17.93) \\
\end{array}$ \\
\hline $\mathrm{Pd}(\mathrm{HL})_{2}$ & $\begin{array}{l}\mathrm{C}_{26} \mathrm{H}_{26} \mathrm{~N}_{8} \mathrm{O}_{4} \mathrm{Pd} \\
620.96\end{array}$ & Yellow & & 69 & $\begin{array}{l}49.11 \\
(50.29)\end{array}$ & $\begin{array}{l}4.01 \\
(4.22)\end{array}$ & $\begin{array}{l}20.41 \\
(18.05)\end{array}$ & $\begin{array}{l}18.44 \\
(17.14)\end{array}$ \\
\hline $\mathrm{Hg}(\mathrm{HL})_{2}$ & $\begin{array}{l}\mathrm{C}_{26} \mathrm{H}_{26} \mathrm{~N}_{8} \mathrm{O}_{4} \mathrm{Hg} \\
715.13\end{array}$ & $\begin{array}{l}\text { Pale } \\
\text { brown }\end{array}$ & 110 & 81.5 & $\begin{array}{l}43.00 \\
(43.67)\end{array}$ & $\begin{array}{l}4.01 \\
(3.66)\end{array}$ & $\begin{array}{l}17.03 \\
(15.67)\end{array}$ & $\begin{array}{l}29.32 \\
(28.05)\end{array}$ \\
\hline
\end{tabular}



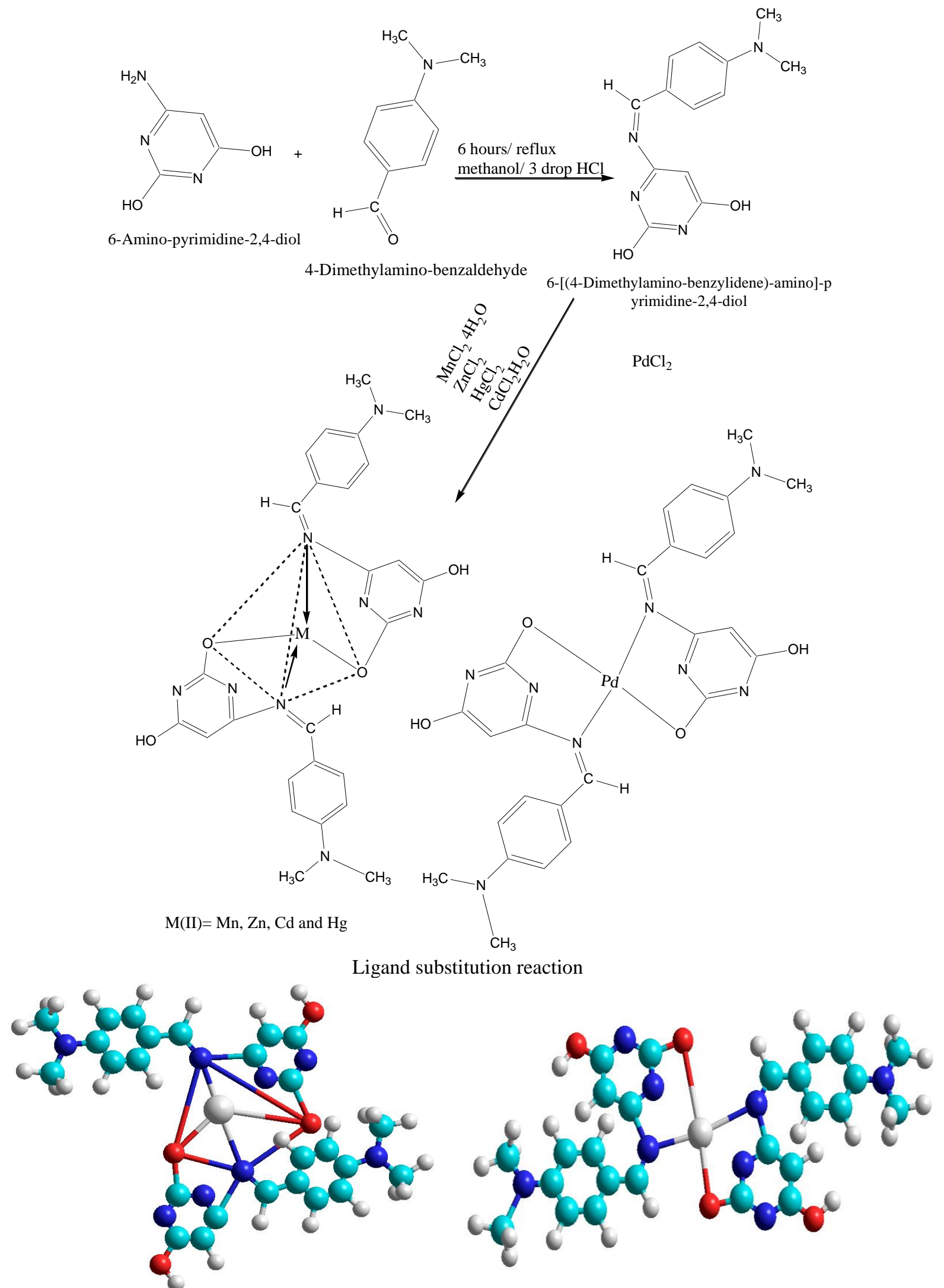

Scheme (1): synthesis of the ligand and complexes and 3D for complexes 


\subsection{IR spectra}

The IR spectrum of $\left(\mathrm{H}_{2} \mathrm{~L}\right)$ ligand (Table 2 and Figure 3) shows characteristic bands at 3425 and $1404,923 \mathrm{~cm}^{-1}$ due to stretching and bending modes vibrations of $\mathrm{OH}$ group, respectively. Also, the spectrum bands observed in the regions 3067 , 2866, 2959, 1608 and $(1713,1655) \mathrm{cm}^{-1}$ may be ascribed to $v(\mathrm{C}-\mathrm{H})$ aromatic, $v(\mathrm{C}-\mathrm{H})$ aliphatic, $v(\mathrm{C}-\mathrm{H})$ aldehyde, $(\mathrm{C}=\mathrm{C})$ and $\mathrm{v}(\mathrm{C}=\mathrm{N})$ azomethine, respectively.[9, 10]. The IR spectra of metal complexes are represented. These spectra exhibit ligand bands with appropriate shifts due to complex formation (Table 2). The data refer to the following observations. The stretching vibration of $(\mathrm{C}=\mathrm{N})$ in all complexes exhibits change in shape and undergoes downshift via $13-44 \mathrm{~cm}-1$, indicating its contribution in chelation. The IR spectra of metal complexes depicted weak spectral bands at 401-476 and 490-506 $\mathrm{cm}^{-1}$, which may be due to $v(\mathrm{M}-\mathrm{O})$ and $v(\mathrm{M}-\mathrm{N})$, respectively. [1013]. the aforementioned infrared studies indicated that the ligand acts as neutral ON bidentate moiety in all complexes. The metal ions chelated to the ligand through ON donor sites of nitrogen atom of azomethine group and oxygen atom of phenol group to confirm the tetrahedral all complexes except in $\operatorname{Pd}(\mathrm{II})$ complex square planar.

\begin{tabular}{|c|c|c|c|c|c|c|}
\hline compounds & $\mathrm{u}(\mathrm{O}-\mathrm{H})$ phenol & $\begin{array}{l}\text { C-H aromatic } \\
\text { C-H alipatic }\end{array}$ & $\begin{array}{l}\text { C-H aldehyde } \\
C=C\end{array}$ & $\mathrm{C}=\mathrm{N}$ & $M-N$ & M-O \\
\hline \multirow[t]{2}{*}{$\mathrm{H}_{2} \mathrm{~L}$} & 3507 & 3067 & 2959 & 1713 & & \\
\hline & & 2866 & 1608 & 1655 & & \\
\hline \multirow[t]{2}{*}{$\mathrm{Mn}(\mathrm{HL})_{2}$} & 3444 & 3012 & 2984 & 1704 & 506 & 460 \\
\hline & & 2888 & 1624 & 1644 & & \\
\hline \multirow[t]{2}{*}{$\mathrm{Zn}(\mathrm{HL})_{2}$} & 3509 & 3044 & 2974 & 1689 & 497 & 467 \\
\hline & & 2879 & 1623 & 1650 & & \\
\hline \multirow[t]{2}{*}{$\mathrm{Cd}(\mathrm{HL})_{2}$} & 3487 & 3100 & 2977 & 1694 & 490 & 476 \\
\hline & & 2974 & 1616 & 1649 & & \\
\hline \multirow[t]{2}{*}{$\mathrm{Pd}(\mathrm{HL})_{2}$} & 3486 & 3086 & 2984 & 1694 & 501 & 401 \\
\hline & & 2900 & 1625 & 1650 & & \\
\hline \multirow[t]{2}{*}{$\mathrm{Hg}(\mathrm{HL})_{2}$} & 3489 & 3079 & 2973 & 1708 & 497 & 455 \\
\hline & & 2940 & 1631 & 1647 & & \\
\hline
\end{tabular}

\subsection{Atomic absorption spectra and magnetic susceptibilities:}

The electronic spectral to the ligand (Figure 4) show intensive absorption on $465,336 \mathrm{~nm}$ also $268 \mathrm{~nm}$ attributed into $\mathrm{n} \rightarrow \pi^{*}$ also $\pi \rightarrow \pi *$ respectively. The electronic spectral for $\mathrm{Mn}$ (II) complex reveals bands at 490 and $615 \mathrm{~nm}$, assignable to ${ }^{6} \mathrm{~A}_{1} \mathrm{~g} \rightarrow{ }^{4} \mathrm{~T}_{2} \mathrm{~g}$ (4G) overlapped with LMCT and ${ }^{6} \mathrm{~A}_{1} \mathrm{~g} \rightarrow \quad{ }^{4} \mathrm{~T}_{1} \mathrm{~g}$ (4G) transitions, respectively $[14,15]$; confirming the tetrahedral geometry around $\mathrm{Mn}(\mathrm{II})$ ion. The magnatic moment value (5.33 B.M) was an evidence for high spin tetrahedral $\mathrm{Mn}(\mathrm{II})$ complex. The diamagnetic $\mathrm{Zn}$ (II), $\mathrm{Cd}$ (II) and $\mathrm{Hg}$ (II) complexes has an tetrahedral geometry based on analytical, conductance and spectral data. [ 15,16]. The spectrum of diamagnetic $\mathrm{Pd}(\mathrm{II})$ complex gives three bands at 514, 552 and $665 \mathrm{~nm}$ corresponding to LMCT overlapped with ${ }^{1} \mathrm{~A}_{1} \mathrm{~g} \rightarrow{ }^{1} \mathrm{E}_{1} \mathrm{~g},{ }^{1} \mathrm{~A}_{1} \mathrm{~g} \rightarrow$ ${ }^{1} \mathrm{~B}_{1} \mathrm{~g}$ and ${ }^{1} \mathrm{~A}_{1} \mathrm{~g} \rightarrow{ }^{1} \mathrm{~A}_{2} \mathrm{~g}$ transitions, respectively, which is consistent with square planar geometry around $\mathrm{Pd}(\mathrm{II})$ metal ion.[15,17].

\subsection{Mass spectra}

Mass spectrometry will be successfully applied to examine molecular types on solution. Pattern from mass spectral for complexes proves the possible formula as well gives an idea to the successive fragmentations to the target compound for a series from peaks corresponding into diverse fragments. Mass spectral from PdHL complex (Figure 6), displayed delicate parent molecular ion peak on $\mathrm{m} / \mathrm{z}$ (621 amu) consistent with the theoretical molecular weight (620.96). The spectrum predicted the monomeric nature of $\mathrm{Pd}$ complex. The series of peaks corresponding to degradation of the ligand appeared at $\mathrm{m} / \mathrm{z} 488,329$ and 189 amu characterized to [C22H14N4O3Pd]+, [C18H9N4O3]+ and [C8H3N3O3]+, respectively.

Mass spectral from ZnHL complex (Figure 7) offered delicate parent molecular ion peak on $\mathrm{m} / \mathrm{z}$ (580 amu) proportionate for the molecular weight theoretically (579.93). The spectrum predicted the monomeric nature of $\mathrm{Zn}$ complex. The series of 
peaks corresponding to degradation of the ligand appeared at m/z 429, 300, 204 and $76.5 \mathrm{amu}$ characterized to [C22H19N7O3]+, [C14H14N5O3]+, [C8H6N5O2]+, and [C6H4]+, respectively.

Mass spectral from HgHL complex (Figure 8), appeared delicate parent molecular ion peak on $\mathrm{m} / \mathrm{z}$ (715 amu) proportionate for the molecular weight theoretically. The spectral prophesyed the monomeric nature from $\mathrm{Hg}$ complex. The chain of peaks corresponding to the degeneration to the ligand appeared at $\mathrm{m} / \mathrm{z} 430,429,205,204$ and 79amu characterized to $\left[\mathrm{C}_{22} \mathrm{H}_{20} \mathrm{~N}_{7} \mathrm{O}_{3}\right]^{+}$, $\left[\mathrm{C}_{22} \mathrm{H}_{19} \mathrm{~N}_{7} \mathrm{O}_{3}\right]^{+}, \quad\left[\mathrm{C}_{8} \mathrm{H}_{7} \mathrm{~N}_{5} \mathrm{O}_{2}\right]^{+}, \quad\left[\mathrm{C}_{8} \mathrm{H}_{6} \mathrm{~N}_{5} \mathrm{O}_{2}\right]^{+}$and $\left[\mathrm{C}_{6} \mathrm{H}_{7}\right]^{+}, \quad$ respectively $\quad[18, \quad 19]$.
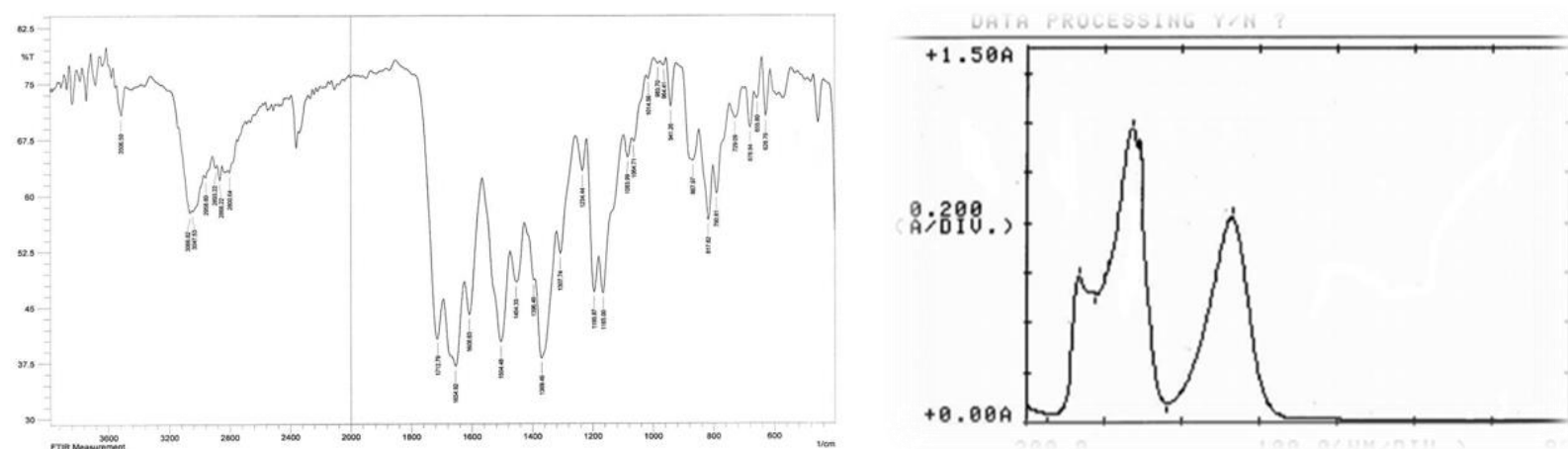

Fig. (3): FT.IR Spectrum of ligand $\mathrm{H}_{2} \mathrm{~L}$

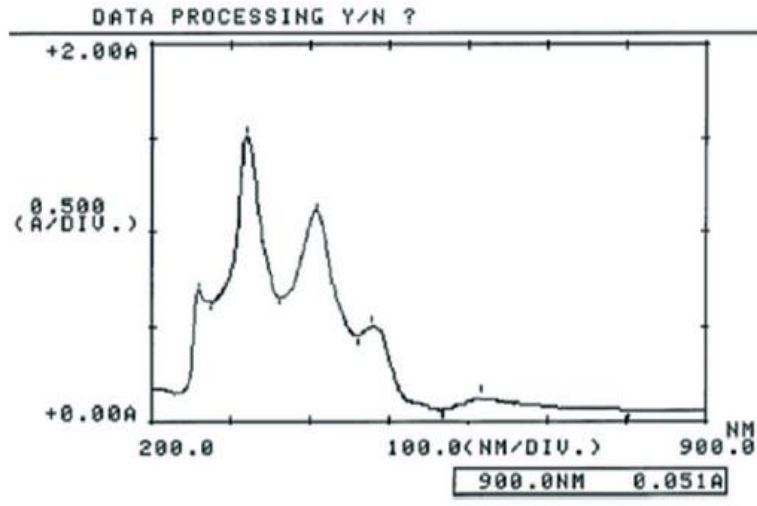

Fig. (4): (UV-Vis) Spectrum of Ligand $\mathrm{H}_{2} \mathrm{~L}$

Fig. (5): (UV-Vis) Spectrum of complex Mn (HL) 2

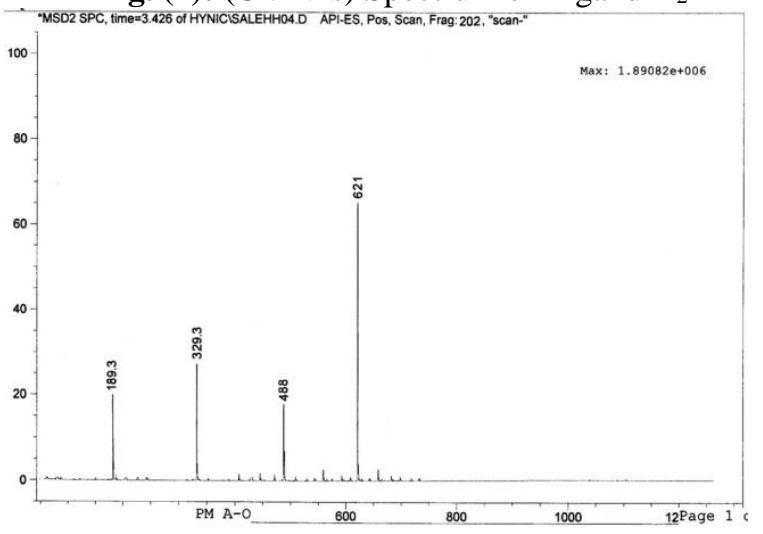

Fig. (6):Mass Spectrum of complex Pd (HL) 2
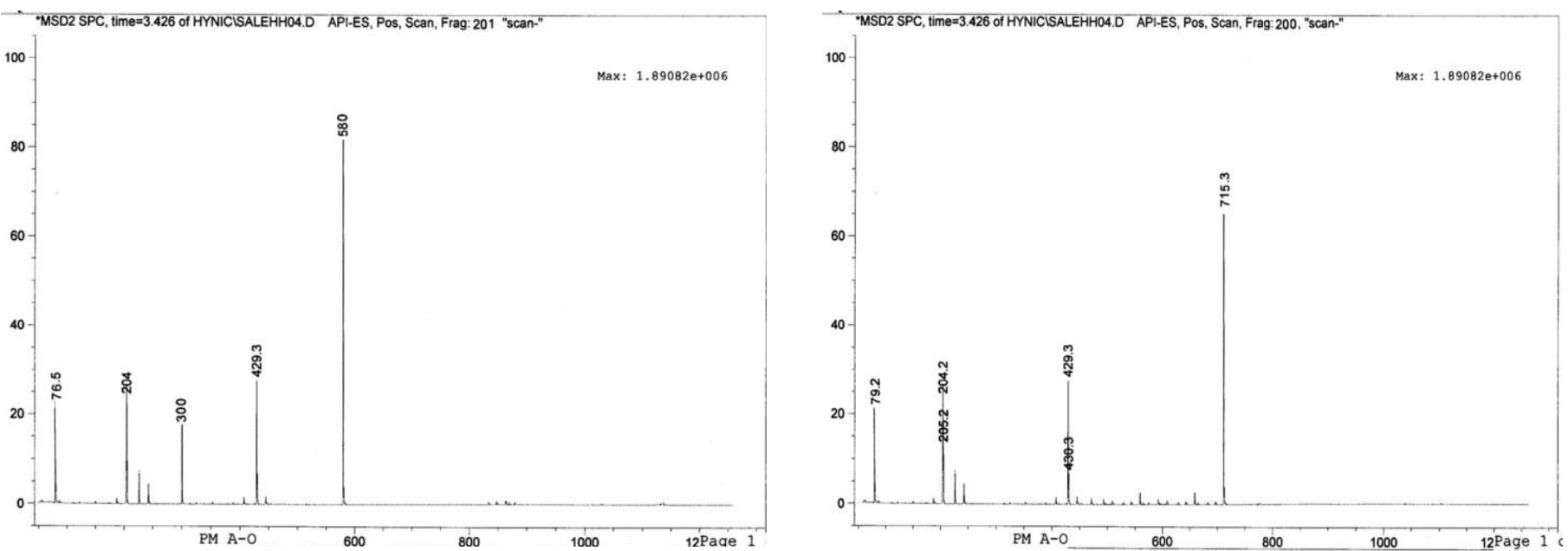

Fig.(7): Mass Spectrum of complex $\mathrm{Zn}(\mathrm{HL})_{2}$

Fig. (8):Mass Spectrum of complex $\mathrm{Hg}(\mathrm{HL})_{2}$ 


\subsection{Statistical Analysis}

All the analysis will be carried out in Excel and expressed as mean Standard deviation, Coefficient of variation \%, Correlation coefficient and IC50 were showed in table (3) to (6), see Figure 9.

Table (3): Means, standard deviations, coefficients of variation, Correlation coefficient and IC 50 of antioxidant activity in percentage (aa\%) of the tested samples at 30. Minute

\begin{tabular}{llllll}
\hline Tested sample & Mean & Standard deviation & Coefficient of varation \% & $\begin{array}{l}\text { Correlation } \\
\text { coefficient }\end{array}$ & IC50 \\
\hline $\mathrm{H}_{2} \mathrm{~L}$ & 48.5 & 23.4512451 & 34.45126522 & 0.97845784 & 0.334 \\
\hline $\mathrm{Mn}(\mathrm{HL})_{2}$ & 82.41 & 4.5123546 & 5.412451464 & 0.99842175 & \\
\hline $\mathrm{Zn}(\mathrm{HL})_{2}$ & 71.11 & 20.1452194 & 27.41576542 & 0.984075954 & \\
\hline $\mathrm{Cd}(\mathrm{HL})_{2}$ & 41.12 & 8.10214875 & 19.74186452 & 0.999918755 & 0.948 \\
\hline $\mathrm{Pd}(\mathrm{HL})_{2}$ & 55.43 & 16.8731974 & 20.45718542 & 0.99745812 & \\
\hline $\mathrm{Hg}(\mathrm{HL})_{2}$ & 23.41 & 26.8271648 & 28.415765485 & 0.880997451 & 1.78 \\
\hline
\end{tabular}

Where IC50: the half maximal inhibitory concentration

Table (4): Means, standard deviations, coefficients of variation, Correlation coefficient and IC50 of antioxidant activity in percentage (aa\%) of the tested samples at 60 . minute

\begin{tabular}{llllll}
\hline Tested sample & Mean & Standard deviation & Coefficient of varation \% & $\begin{array}{l}\text { Correlation } \\
\text { coefficient }\end{array}$ & IC50 \\
\hline $\mathrm{H}_{2} \mathrm{~L}$ & 59.632 & 28.798547 & 49.78421 & 0.99445 & 0.334 \\
\hline $\mathrm{Mn}(\mathrm{HL})_{2}$ & 87.832 & 5.4972183 & 4.978462 & 0.98875 & \\
\hline $\mathrm{Zn}(\mathrm{HL})_{2}$ & 72.19 & 11.8731543 & 16.46152 & 0.99227 & 0.47 \\
\hline $\mathrm{Cd}(\mathrm{HL})_{2}$ & 56.784 & 9.7194318 & 19.74124 & 0.97775 & \\
\hline $\mathrm{Pd}(\mathrm{HL})_{2}$ & 79.784 & 8.419752 & 11.57164 & 0.89748 & 0.741 \\
\hline $\mathrm{Hg}(\mathrm{HL})_{2}$ & 26.487 & 4.527198 & 4.99147 & 0.99974 & \\
\hline
\end{tabular}

Where IC50: the half maximal inhibitory concentration

Table (5): Means, standard deviations, coefficients of variation, Correlation coefficient and IC50 of antioxidant activity in percentage (aa\%) of the Gallic acid at 30. minute.

\begin{tabular}{|c|c|c|c|c|}
\hline Test sample & Mean & Standard deviation & $\begin{array}{l}\text { Coefficient of varation } \\
\%\end{array}$ & Correlation coefficient \\
\hline Gallic acid & 89.741 & 3.4175421 & 2.974851 & 0.97845718 \\
\hline
\end{tabular}

Table (6): Means, standard deviations, coefficients of variation, Correlation coefficient and IC50 of antioxidant activity in percentage (aa\%) of the Gallic acid at 60 . Minute

\begin{tabular}{|c|c|c|c|c|}
\hline Test sample & Mean & Standard deviation & $\begin{array}{l}\text { Coefficient of varation } \\
\%\end{array}$ & Correlation coefficient \\
\hline Gallic acid & 90.0041 & 2.44152 & 2.07415741 & 0.9700045 \\
\hline
\end{tabular}




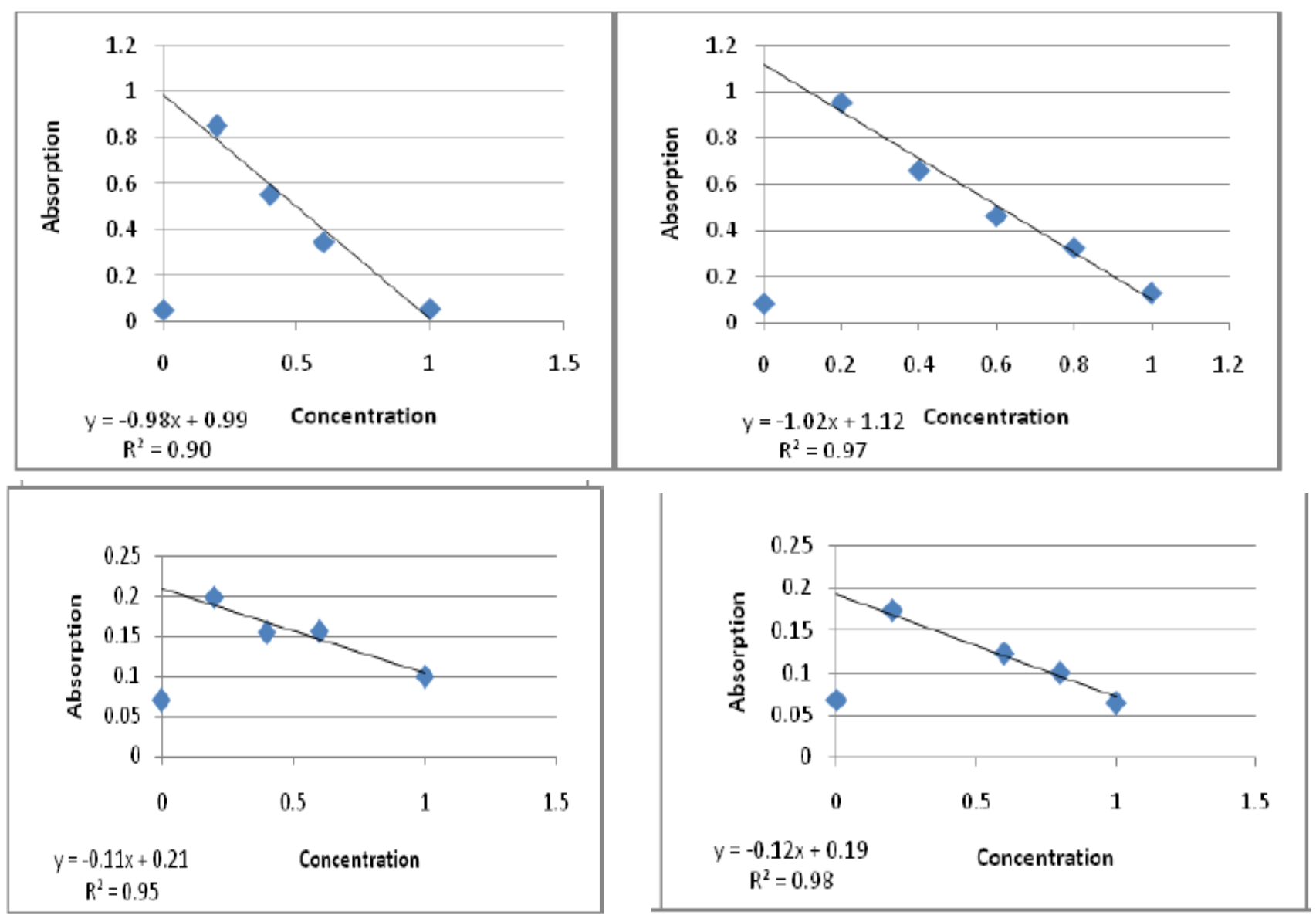

Fig. (9): Standard curve of ligand and Ni complex at 30 and 60min.

\subsection{Spectrophotometric determination of DPPH radical scavenging efficiency}

Most investigations are conducted like DPPH are conducted to assess the anti-oxidant efficiency of their aims because of its simple proceeding accuracy. The DPPH radical results of the scavenging efficacy to the compounds are depicted depending on the Table 1. Lower Depress IC50 value reflects better DPPH radicalscavenging efficacy. According to the table, it will be evident that nearly all the compounds display radical scavenging efficacies on DPPH test. It will be important to note that Schiff base of the complex displayed better anti-oxidant efficacy than Schiff base (an according to the Table 8). The existence for Schiff base as well -OH groups too has impact at DPPH radical scavenging efficiency also ethylene spacer does not have any influence to the characteristic of the anti-oxidant. So while a check the sample solution is added, free radical is equalized through the exam sample which, either donate hydrogen or an electron whom outcome neutralization from free radical. While the free radical is neutralized during screening sample less free radical will be obtainable $[6,7]$.

\section{CONCLUSION}

In such paper synthesis as well description from novel complexes for generic formula [M $\left(\mathrm{H}_{2} \mathrm{~L}\right)$ 2] for $(\mathrm{M}=\mathrm{Mn}(\mathrm{II}), \mathrm{Cd}(\mathrm{II}), \mathrm{Zn}(\mathrm{II}), \mathrm{Pd}(\mathrm{II})$ and $\mathrm{Hg}(\mathrm{II})$ complexes will prepared from this ligand. The characterization of ligand and its metal complexes will done by elemental microanalyses and spectral techniques. The complexes of $\mathrm{Mn}$ (II), $\mathrm{Cd}(\mathrm{II}), \mathrm{Zn}(\mathrm{II}), \mathrm{Hg}$ (II) and $\mathrm{Pd}(\mathrm{II})$ chloride will be nonelectrolytes. The ligand behaved as neutral ON bidentate moiety in all complexes. All complexes will be tetrahedral except that of $\mathrm{Pd}(\mathrm{II})$ which has square planar geometry. The radical scavenging efficiency from Schiff base as well its complexes were scrutinized utilizing DPPH screening. Anti-oxidant mensuration's from attended compounds explained 
that the $\mathrm{OH}$ functional groups as well the existence from electron donating significantly impact the radical scavenging efficiency from phenolic Schiff bases.

\section{REFERENCES}

A. Antony Shanty, P. V. Mohana,( 2018), Heterocyclic Schiff bases as nontoxic antioxidants: solvent effect, structure activity relationship and mechanism.Spectrochim. Acta A, 192, 181-187.

P. E, Ikechukwu, P. A. Ajibade,( 2016), Synthesis, Characterization, Anticancer, and Antioxidant Studies of Ru (III) Complexes of Monobasic Tridentate Schiff Bases. Bioinorganic Chemistry and Applications, 1-11.

Lai LS, Chou ST, Chao WW.,( 2001),Studies on the antioxidative activities of Hsian-tsao (MesonaprocumbensHemsl) leaf gum, J. Agric. Food Chem., 49(2), 963-968.

W. Al Zoubi, A. A. S. Al-Hamdani, M. Kaseem.,( 2016),Synthesis and antioxidant activities of Schiff bases and their complexes: a review., App. Organomet Chem., , 30(10), 810-817.

C. Onwudiwe, A. C. Ekennia,( 2017), Synthesis, characterization, thermal, antimicrobial and antioxidant studies of some transition metal dithiocarbamates. Res. Chem. Intermed., 43, 1465-1485.

I. Gulcin, M.E. Buyukokuroglu, M. Oktay, O.I. Kufrevioglu,( 2002),In vitro antioxidative properties of melatonin, J. Pineal Res., 33(3), $167-171$

W. Al Zoubi, A. A. S. Al-Hamdani, S. D. Ahmed, H. M. Basheer, R. S. A. Al-Luhaibi, A. Dib and Yo Gun Ko.,(2018),Synthesis, characterization, and antioxidant activities of imine compounds. J Phys Org Chem.; e3916, 1-9.

W. Al Zoubi, F. Karabet, R. Al Bandakji, K. Hussein,( 2017),Experimental and theoretical investigations of the antioxidant activity of 2,2'- methylenebis(4,6- dialkylphenol) compounds. Applied OrganometallicChemistry. 31(2), 3562,

Silverstein, R. M, Bassler, G. C, Morril, T. C.( 1980),Spectrometric Identication of organic compounds. 4th Ed.: 111-133.

Al-Hamdani A. A. S. and Hamoodah R. G.,( 2016 ), Transition Metal Complexes with Tridentate
Ligand: Preparation, Spectroscopic Characterization, Thermal Analysis and Structural Studies, J. Baghdad for science, 13(4), 770-781,.

A. S. Abbas, A. S. Shayma,( 2011).J. Oriental, Chemistry, 27, 835.

Nakamoto, N., (2009), Infrared and Raman Spectra of Inorganic and Coordination Compounds, 6thEd, Part 2 John Wiley and Sons, Inc., New Jersy.

S. M. Abdallah, M.A. Zayed, G. G. Mohamed.,(2010),Synthesis and spectroscopic characterization of new tetradentate Schiff base and its coordination compounds of NOON donor atoms and their antibacterial and antifungal activity., Arbian J. Chem., 3(2), 103113.

Abbas Ali Salih Al-Hamdani, Maher Abdulrazk Mohammad Alta'yy, Nawres Khalid Gabraael Al-dulyme.,( 2017), Synthesis, Spectroscopic and Theoretical Studies of Some New Transition Metal Complexes with Mixed ligands Schiff Base and Bipyridyl., Ibn Al-Haitham Jour. for Pure \& Appl. Sci. 30(2) 69-83.

Balkhi, A. M. and falah, A. and Shaker, Sh. A.( 2015). New Azo-Schiff base Derived with Ni(II), $\mathrm{Co}(\mathrm{II}), \mathrm{Cu}(\mathrm{II}), \mathrm{Pd}(\mathrm{II})$ and $\mathrm{Pt}(\mathrm{IV})$ Complexes: Preparation, Spectroscopic Investigation, Structural Studies and Biological Activity. J. Chil. Chem. Soc.; 60(1): 2774-2785.

Al-Hamdani A.A. S., Jarad A. J. and Al-Atrakchi S. A.,( 2009), Synthesis and Spectral Analysis of $\mathrm{VO}(\mathrm{II}), \mathrm{Cr}$ (III), $\mathrm{Zn}(\mathrm{II}), \mathrm{Cd}(\mathrm{II}), \mathrm{Hg}$ (II) and UO2 (II) Complexes with Mixed Ligands of Bipyridyl and Novl Schiff Base, Diala J., 36, 114 ,.

W. Al Zoubi, A. A. S. Al-Hamdani, S. D. Ahmed, Y. G. Ko.,( 2017), A new azo-Schiff base: Synthesis, characterization, biological activity and theoretical studies of its complexes. Appl Organometal Chem.; 3895 , 1-15.

Al-Hamdani, A. A.S, Balkhi, A. M, Falah, A, Shaker, Sh. A.( 2015)J. Chil. Chem. Soc. 60 (1) 27742785.

W. Al Zoubi, A. A. S. Al-Hamdani, I.P. Widiantara, R. G. Hamoodah, Y. G. Ko,( 2017),Theoretical studies and antibacterial activity for Schiff base complexes. J. Phys. Org. Chem.,30(12), 3707. 


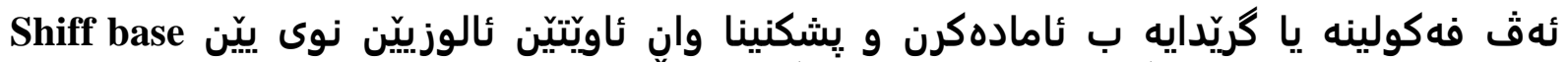

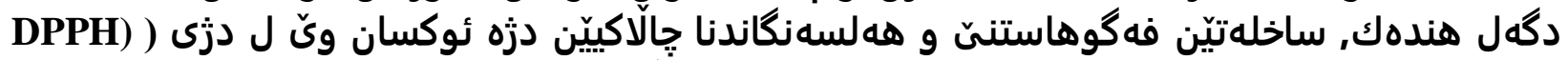

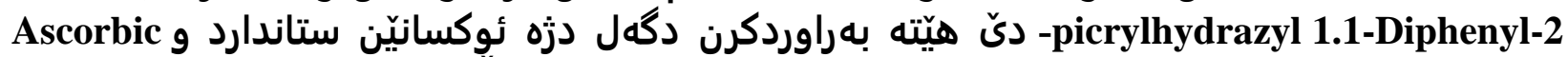
كار acid

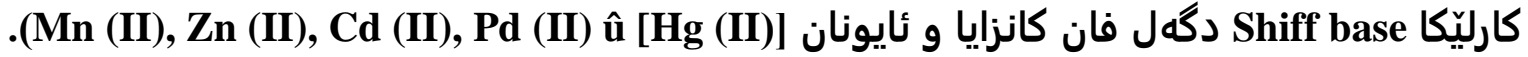

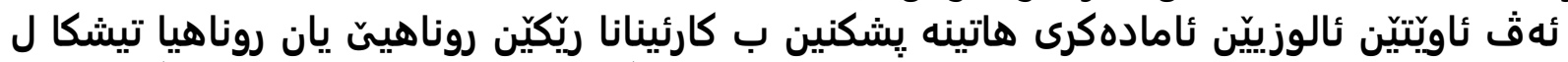

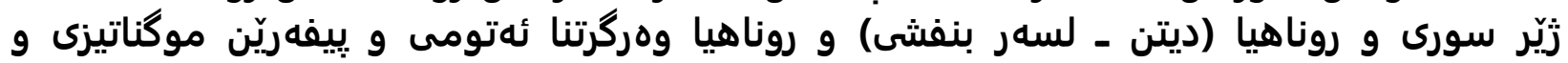

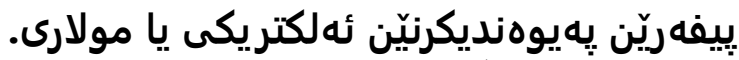

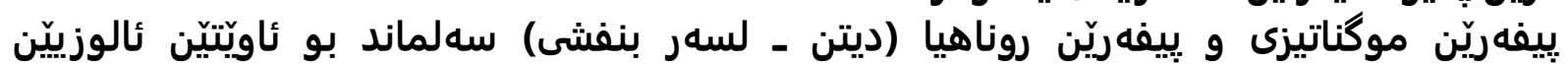

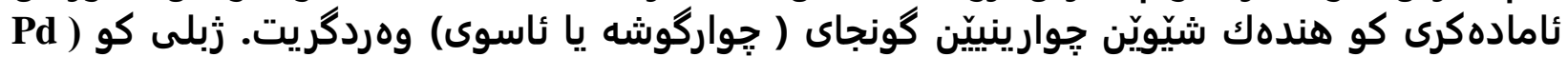

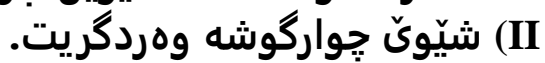

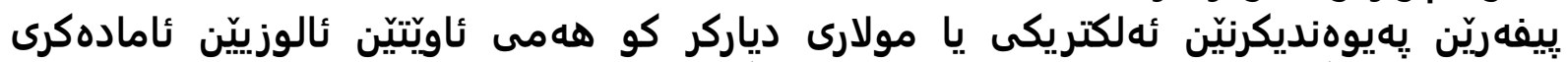

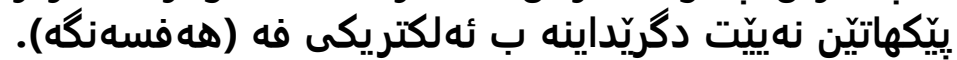

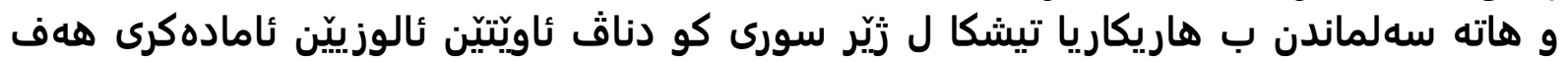

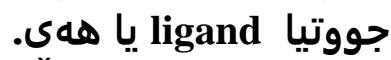

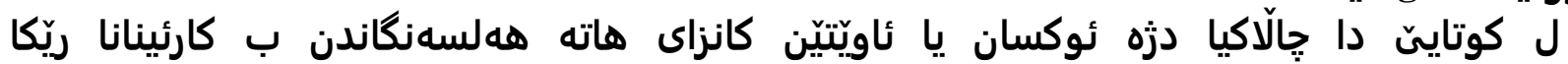

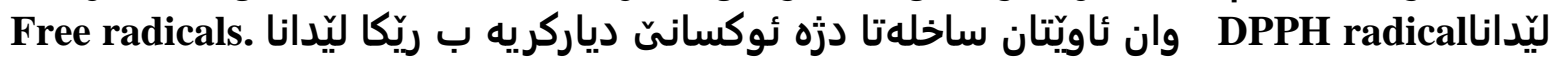
الخلاصة

الخلاص تحضير وتشخيص قاعدة شف ومعقدات الايونات الفلزية وتقييمها كمضادات للاكسدة -1,1) وهي مادم ومقارنتها مع مضادات الطبيعية ومنها حمض الطفات الأسكوربيك

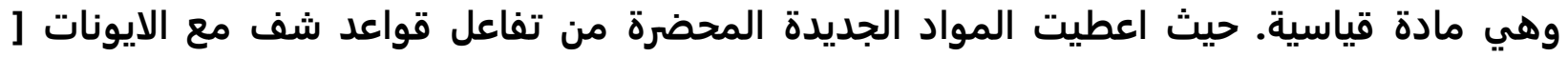
[ (Mn(II), Zn (II), Cd(II), Pd(II) and Hg(II ط ش (DPPH)

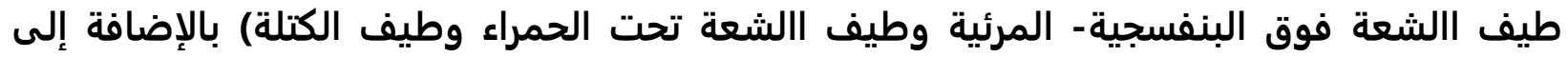

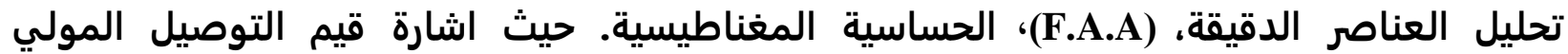

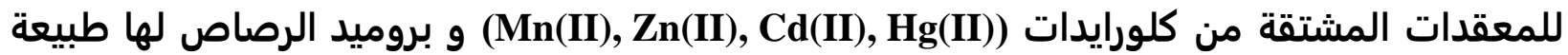

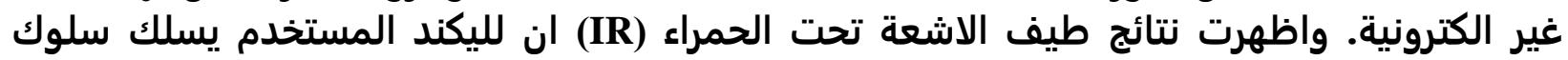

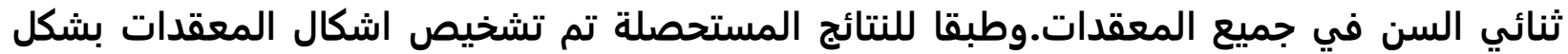

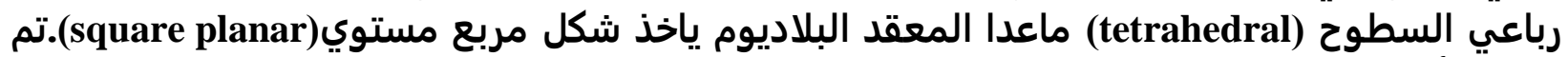
فحص أنشطة مضادات الأكسدة في المعقدات الفلزية باستخدام طريقة للمعقدات. 